Article

\title{
Smart Cities as Organizational Fields: A Framework for Mapping Sustainability-Enabling Configurations
}

\author{
Paul Pierce ${ }^{1}$ (1) , Francesca Ricciardi $^{2}$ (1) and Alessandro Zardini ${ }^{2, *}$ \\ 1 Department of Informatics, School of Economics and Management, Lund University, 22100 Lund, Sweden; \\ paul.pierce@ics.lu.se \\ 2 Department of Business Administration, University of Verona, 37129 Verona, Italy; \\ francesca.ricciardi@univr.it \\ * Correspondence: alessandro.zardini@univr.it; Tel.: +39-045-802-8565
}

Received: 31 July 2017; Accepted: 21 August 2017; Published: 24 August 2017

\begin{abstract}
Despite the impressive growth of smart city initiatives worldwide, an organizational theory of smart city has yet to be developed, and we lack models addressing the unprecedented organizational and management challenges that emerge in smart city contexts. Traditional models are often of little use, because smart cities pursue different goals than traditional organizations, are based on networked, cross-boundary activity systems, rely on distributed innovation processes, and imply adaptive policy-making. Complex combinations of factors may lead to vicious or virtuous cycles in smart city initiatives, but we know very little about how these factors may be identified and mapped. Based on an inductive study of a set of primary and secondary sources, we develop a framework for the configurational analysis of smart cities viewed as place-specific organizational fields. This framework identifies five key dimensions in the configurations of smart city fields; these five dimensions are mapped through five sub-frameworks, which can be used both separately as well as for an integrated analysis. Our contribution is conceived to support longitudinal studies, natural experiments and comparative analyses on smart city fields, and to improve our understanding of how different combinations of factors affect the capability of smart innovations to translate into city resilience, sustainability and quality of life. In addition, our results suggest that new forms of place-based entrepreneurship constitute the engine that allows for the dynamic collaboration between government, citizens and research centers in successful smart city organizational fields.
\end{abstract}

Keywords: organizational fields; organizational logics; smart city; sustainable city; sustainability transformation; innovation ecosystem; sustainable entrepreneurship

\section{Introduction}

The multidisciplinary scholarly community that studies the dynamics of sustainability transformations often complains that social phenomena such as intractable ideological conflicts, lack of coordination, cultural habits, or normative inertia, hinder positive change [1]. The literature provides descriptions of several cases in which such social and organizational issues translate into the failure of sustainability-oriented innovations, even if this innovation is based on technologically and economically viable solutions [2]. Actually, we do not know enough about how these issues could be addressed. For example, the literature on the adaptive co-management approach [3] underlines the absence of vast conceptual tools for analyzing the social dynamics in the economic communities that depend on protected natural resources $[4,5]$. This gap dramatically diminishes the capabilities to organize for resilient social-ecological systems.

It is increasingly clear that an effective theoretical approach is needed to better understand, measure and govern the social and organizational dynamics that are key to sustainability 
transformations [6]. Some recent seminal articles suggest that the research on institutional logics can provide such theoretical tools [7]; consistently, the organizational field [8] is a good candidate as the most appropriate level of analysis for sustainability transformations [9]. Studying the organizational field and the dynamics of institutional logics enables us to better understand the interplay of all the relevant social actors that (are expected to) play an active role in a specific sustainability transformation, such as businesses, start-ups, research centers, government bodies or social movements. Even more importantly, this approach provides effective tools to understand how, and under what conditions, a sustainability-oriented distributed activity system can emerge from actors' interplay at the field level.

This study contributes to this emerging stream and adopts the organizational field approach to investigate a phenomenon that has attracted a booming interest in both practice and research: the smart city.

The smart city idea emerged in the 1990s as a response to the paramount challenges of urban environments. A smart city approach implies the exploitation of high technologies, and particularly information and communication technologies (ICT), to improve city resilience and quality of life, along with its economic, social and environmental sustainability [10-13]. The smart city idea has much in common with the sustainable city movement [14], but is characterized by a particular focus on technology-enabled innovation as the key means to achieve sustainability. Therefore, entrepreneurship is expected to play a pivotal role in smart city initiatives $[15,16]$, since new opportunities must be discovered, and new business models must be developed [17], for the smart city idea to translate into practice.

Paramount investments have been made worldwide to develop smart city projects [18]. Some leading global players in the ICT and consulting sectors have significantly contributed to the development of the smart city idea. However, despite these impressive investments and endeavors, the results of smart city initiatives have often been partial, and in some cases, frankly disappointing $[19,20]$. Faced with these failures, smart city practitioners and researchers are developing a growing awareness that the traditional organizational and management approaches are poorly equipped to address the novel challenges posed by the smart city context and goals [11]. In other words, smart city initiatives suffer from the same knowledge gap that affects many other efforts to organize system-level sustainability transformations [1].

In particular, the smart city context is characterized by a strong interdependence between the city government, the citizens, and the city's ecosystems of researchers, innovators and entrepreneurs [21]. We argue that this interdependence poses unprecedented challenges to organization and management scholars. However, up to now, we lack an organizational theory of the smart city, and consistently we lack structured frameworks aimed to understand and manage the relevant social dynamics of the smart city activity system.

This study addresses this gap by conceptualizing the smart city as an organizational field and develops a framework for the multi-dimensional configurational analysis of smart city fields, thus contributing to the development of a structured view of the different possible designs of smart city meta-organizations.

The proposed framework is based on an inductive study of primary and secondary sources. The framework identifies five key aspects for the configurational analysis of smart city fields. Three of these aspects (Actors, actors' Roles, and Institutional Logics) are typical key dimensions of all organizational fields and their importance in the smart city cases under analysis confirms the existing institutional theories; conversely, the remaining two aspects (City Sub-Systems and Activity Layers) are specific to smart city contexts and emerge from a grounded analysis of our primary and secondary sources. In other words, a mixed top-down and bottom-up analysis led to the identification of the framework proposed by this study.

For each of the five dimensions of the configurational analysis proposed by this study, a list of the typical and relevant possible conditions is provided. Each smart city can be characterized by a specific combination of conditions for each dimension of the configurational analysis. The framework 
allows for both the analysis of an individual dimension, and the integrated analysis of two or more dimensions of the smart city field. This will allow scholars to use this framework for longitudinal analyses, comparative analyses, as well as natural experiments. We also suggest that the lenses provided by this five-dimension framework may help researchers detect and map the innovation dynamics and emerging business models in smart city fields.

In its final part, this article provides brief examples of how to leverage the proposed framework in the data collection phase. These examples show that the framework has a good degree of modularity and granularity, thus allowing scholars to effectively map many relevant aspects of smart city fields. Smart city fields are complex social organisms characterized by idiosyncratic processes of hybridization between different institutional logics, relational networks and rules [22]: therefore, each city launching smart city initiatives results in a place-specific institutional environment. Mapping these aspects under a consistent theoretical approach is a first, necessary step to understand the organizational factors that may enhance the contribution of smart city initiatives to city resilience, sustainability and quality of life.

While contributing to the smart city literature, this study also contributes to the literature on institutional logics and organizational fields. The most recent developments from this viable stream of studies have overcome the classical views of organizational fields as either stable environments populated by passive, conformist actors driven by legitimacy needs, or exclusively competitive arenas, shaped by actors' struggles to increase their power [8]. These initial views of organizational fields enabled innumerable and very interesting analyses, but were poorly equipped to explain sustainability transformations, for at least two reasons. First, traditional institutional theories are ethically neutral and study the influence of institutional phenomena in organizational life (and vice versa) without considering positive societal impact as an expected outcome. Second, sustainability transformations are extremely complex phenomena, in which innovation and compliance, cooperation and competition, communities and businesses continuously intertwine in both vicious and virtuous cycles that cannot be understood through the traditional structure-agency polarization that characterized classical institutional studies [23]. Not surprisingly, today many institutional scholars seek to overcome these limits and understand organizational fields as highly complex and dynamic relational spaces, where hybrid and continuously evolving forces are in action, whose interplay is crucial for sustainability transformations [1]. However, this approach is still in its infancy, and we still lack operationalizable models to conduct deductive empirical research in specific, complex organizational fields where sustainability transformations are needed [6]. Smart cities are extremely interesting contexts to take on this challenge, but have been overlooked by organizational scholars so far. For this reason, we deem that our study could be of interest also for researchers who are engaged in institutional studies.

\section{Theoretical Foundations}

\subsection{Organizational Fields, Institutional Logics, and Sustainability-Enabling Resilience}

When higher-order societal institutions emerge, such as professional associations, government bodies, religions, social movements or communities, these institutions trigger and enable regular interactions across specific groups of social actors (such as organizations), which consequently tend to progressively cohere on specific sets of shared rules and beliefs. For example, in certain governmental bodies and big corporations, strong inertial rules and beliefs may be developed that prioritize procedural correctness and hierarchical control over results: as a consequence, a social environment shaped by a bureaucratic logic emerges. Many such sets of consistent rules and beliefs exist at the societal level (e.g., the classical market logic, the charity logic, etc.). These sets, called institutional logics, are at the core of institutional studies, a viable research stream at the intersection of sociology, political science, and organizational science [24].

Institutional logics provide actors with socially shared, deeply held rules of the game, assumptions and values that shape cognitions and behaviors and form the basis for legitimacy. Institutional logics 
are embodied in practices, discourses and even the physical environment: for example, the architecture of school buildings strongly depends on the institutional logics under which these buildings were designed [25]. Institutional logics are essential to societies and activity systems, since a recognized logic allows for predictability, mutual understanding and a sense of common identity, and consequently large-scale cooperation $[8,26]$.

The adoption of the concept of organizational logic injects significant explanatory power in organizational research. On the one hand, organizations are strongly affected by the logics of their institutional environment; on the other hand, organizations may also work as powerful engines that modify the existing logics or even create new ones through everyday practice and interactions, and in some cases through purposeful institutional work [27-30].

There is wide consensus on adopting the organizational field as the appropriate level of analysis to investigate the dynamics of institutional logics [8]. An organizational field is a relational space, populated by social actors such as businesses, government agencies, social movements, or communities, which: (i) are engaged in similar or intertwining activity systems; and (ii) interact and/or refer to each other under the influence of institutions of common interest. The concept of the organizational field can be applied at the global, national, regional, or local level. For example, law firms are embedded in a well-distinguishable organizational field at the national level.

Some organizational fields are stable systems, with one dominant logic that drives field-level practices; however, most fields are heterogeneous and characterized by several different, often conflicting, institutional logics [31,32]. This incoherence is frequent, for example in green entrepreneurship fields, whose actors have to respond to both environmentalist and market logics. Both opportunities and threats stem from this incoherence. On the one hand, the tensions and contradictions between hardly compatible logics threaten the organizations with disrupting conflicts and paralysis; on the other hand, these same tensions and contradictions are sources of dynamism and innovation [8]. In other words, field incoherence can evolve into virtuous or vicious cycles, depending on the different constellations of coexisting logics, their reciprocal compatibility, and the relating organizational responses [32,33].

Adopting the organizational field as the level of analysis, therefore, can prove a very effective strategy for investigating the organizational conditions for successful sustainability transformations. By "sustainability transformations" [9], the literature usually indicates all those multi-level change processes (in production processes, laws, business models, people's behavior, etc.) that target an improved balance of economic, social and environmental sustainability [34-37]. The analysis conducted at the organizational field level allows researchers to study the dynamics of the intertwining habits, prejudices, cognitive attitudes, values, traditions, legitimacy needs and normative inertia that often affect any innovation process, often quite independently from supposedly objective or "rational" interests. In this light, it is not surprising that an increasing consensus is emerging on the importance of institutional logics and organizational fields for building the organizational conditions for sustainability transformations $[7,38,39]$. It is increasingly clear that sustainability cannot be reduced to a matter of compliance to sustainable norms and practices, because the eco-socio-technical systems continuously change in unpredictable ways, while knowledge on sustainability-related issues is always partial and subject to rapid obsolescence. In this light, the system's sustainability-enabling resilience, rather than sustainability in itself, should be understood as the key measure of organizational fields' success. Resilience can be generally defined as a system's capability to resist crises and to leverage its own difficulties and mistakes as evolutionary opportunities to learn and get stronger $[40,41]$. By "sustainability-enabling resilience", consistently, we indicate: (i) a system's capability to resist crises without jeopardizing the system's own long-term economic, social and environmental sustainability; along with (ii) the system's capability to leverage its own difficulties and mistakes as evolutionary opportunities to learn about the sustainability challenges it faces and adapt accordingly. Consistent with the most recent findings in the literature on the adaptive co-management of the commons [3,42,43], we argue that the organizational fields that develop this type of sustainability-enabling resilience 
make the actors more willing and capable to take care of the social-ecological system they depend on. If the sustainability-enabling resilience of the relevant organizational field(s) is high, a social-ecological system is more likely to get away from points of no return (i.e., economic, social and/or environmental collapse), resist crisis, and evolve towards ever-increasing levels of sustainability. Through what Ferrero et al. [1] call "robust action", these fields result in sustainability transformations through evolutionary learning, which occurs when field-level dynamics (rather than just individual organization-level decisions) enable the continuous experimentation of new sustainable ways to (re)generate resources. According to the theory of robust action, this continuous experimentation is much more likely to enable adaptive change towards improved sustainability if the innovative experimentation processes are distributed, i.e., conducted by several actors in several different ways, whilst a participatory structure allows for knowledge exchange, collective sensemaking, and, if necessary, activity coordination across actors [9]. In other words, the most recent developments of the literature suggest that field-level distributed innovativeness is a key factor for achieving sustainability-enabling resilience. Therefore, we argue that organizational fields need to be fertilized by a new form of entrepreneurship that does not limit itself to innovating products, processes and business models for competitive advantage [44], but is also actively engaged in the sustainability-oriented evolution of knowledge, norms, expectations, beliefs, attitudes and behaviors at the field level. In the light of the Austrian school of economics [45], and particularly Lachmann's work [46], it is increasingly clear that entrepreneurship, and particularly opportunity discovery and development, are socially embedded phenomena [47]. In this view, entrepreneurs may create opportunities by actively participating in the processes of sustainability-oriented institutional experimentation and change of their social environment. The recent research stream on institutional entrepreneurship [30,48-50] provides interesting insights on the role of entrepreneurial capabilities in the complex processes of institutional evolution that are needed for sustainability transformations $[5,16,51]$.

\subsection{The Smart City as an Organizational Field}

Both in the scholarly world and practice, "smart city" is a buzzword that has boomed in the last two decades [52]. Innumerable articles and books have been published so far on this issue, most of which present technological solutions implemented in specific cases and highlight the potential of data-driven innovation at the city level $[53,54]$. However, some criticism is also emerging: for example, Glasmeier and Nebiolo [19] claim that smart city initiatives have so far delivered modest results compared to the promises of the typical optimistic smart city discourse. It is becoming increasingly clear that, in the absence of multi-level cooperation [55], innovative and "smart" technological solutions are not sufficient to positively affect sustainability [10]. In other words, technological innovation runs much faster than organization and management research and practice. The smart city phenomenon is so complex and dynamic that finding the theoretical lenses to understand it is a tough challenge. As Romolini et al. [56] highlight, we lack frameworks to guide the integration of social and ecological phenomena at the city level, therefore analyzing and governing the role of new technologies between these two intertwining phenomena is particularly difficult [18].

However, some recent publications pioneered a new generation of smart city studies, in which organization, management and entrepreneurship issues are at the center of the investigation.

A first key issue that emerges from these studies is the integration between and across smart initiatives. Smart projects are often handled by single departments of the city administration, and then may suffer from the same "silos-based management" that traditionally affects bureaucratic organizations [18]. This hampers collaboration, knowledge exchange and learning [11], often resulting in wasted resources and rapid obsolescence of the smart initiatives, in sharp contrast with the smart city idea, which is based on the multidimensional and dynamic integration of innovative projects [57]. In this light, what makes an urban project smart is the collaboration across related city sub-systems, such as mobility and energy, rather than the adoption of high-tech solutions per se [58]. 
A second important issue that emerges from the recent literature is the debate between the top-down and the bottom-up approach in the management of smart city project portfolios. Some authors view the smart city as a strategic planning challenge, to be addressed by managing the relationship between the city government and the vendors of smart solutions, such as specialized global consultancy firms [59]. Other authors claim that this wedding of big global vendors and local governments results in a substantially vendor-driven top-down approach that loses touch with reality and leaves little room to the concrete needs of ordinary people [60,61]. A growing line of research proposes, instead, a bottom-up, actor-oriented architecture [62] for managing smart city initiatives $[63,64]$. This line of research converges with the steadily growing attention to local entrepreneurship as the core engine of viable smart innovation [21,64-68], because entrepreneurs can (re)build new tailored business models that fit a specific city's needs and conditions.

However, a higher-level vision of the city's sustainable future is needed to orient entrepreneurs' efforts, and the government plays an often irreplaceable role in providing this vision, bringing the necessary resources and facilitating the interactions between the relevant actors that are expected to contribute to smart city initiatives [15]. The citizens should be actively involved in these collaborative interactions, because users' appreciation of, and commitment to, urban change is almost always essential to smart initiatives' success [63]. Effective collaborative interactions between startups/entrepreneurs, scientists and citizens [69-71] allow for viable, distributed experimentation on concrete city-level needs [64]. Universities are expected to support and/or directly participate in these networks, thus activating the so-called triple helix (university, industry and government) [72].

This novel scenario poses unprecedented challenges to organization and management research, because it results in hybrid roles: for example, citizens are expected to contribute to urban entrepreneurship; entrepreneurs are expected to catalyze scientific research and policy-making; while public employees are expected to become intrapreneurs, i.e., active contributors in a community of innovators [73]. In such a context, really innovative solutions for actors' coordination are needed [74]. In fact, this collaborative approach to smart cities tends to result in emerging working groups or "coalitions of the willing" that work outside traditional hierarchical structures, but need acceptance on the part of incumbent actors anyway [64]. Inevitable tensions emerge when innovators and entrepreneurs seek to engage with local governments and citizens in an effort to improve sustainability, resilience and quality of life at the city level [75]. In order to address these tensions successfully, it is crucial to understand all actors' assumptions as for the expected social and commercial gains that may stem from engagement [76], and particularly the tensions and dilemmas relating with common resources [18].

All these studies converge in suggesting that smart city initiatives' success depend on the collaboration and intertwined dynamics of a wide range of different actors, far beyond traditional organizational boundaries and strategic planning approaches. On the other hand, the smart city idea nurtures a vast global movement, advocated by highly reputed corporations and consulting firms [18]. In addition, smart city initiatives are also strongly encouraged by government funding and/or competitive grants, especially in the European Union, but also in the United States and almost all the most important countries worldwide [15]. Going "smart" is perceived as highly fashionable in the political arena and leaders feel that launching smart initiatives is an important factor to attract investments and talents, especially in the high-tech sectors. These evolving perceptions are resulting in the emergence of new rituals of the smart city global community, including the participation in novel dedicated conferences and events [11]. Cities struggle to quickly build a "smart façade" for interacting in the international scenario, while universities and research centers compete to be acknowledged as leading actors of the innovation processes that have to do with smart cities and the Internet of Things (IoT) because these areas are perceived as highly dynamic and prestigious [19]. All these aspects of the emerging smart city phenomenon are consistent with institutional theories; quite surprisingly, however, institutional theories have not been adopted in smart city studies so far. This encourages us to investigate the smart city phenomenon through the lens of institutional logics and organizational 
fields, rather than other traditional theoretical approaches such as the organizational populations, network organizations or industrial sector views (see for example [77]).

The smart city field may be studied at the global, national or urban/regional level. In this study, we focus on smart cities as emerging organizational fields at the urban/regional level. We suggest that this approach is extremely promising, because it provides powerful theoretical tools to understand the complex dynamics that make each city's experience evolve in a particular way, although embedded in the global smart city movement. In addition, the local organizational field has proved to be an excellent level of analysis in order to better understand the role of all forms of place-based entrepreneurship (including social entrepreneurship, green entrepreneurship, and intrapreneurship) (see for example [78]).

A keyword search conducted in Google Scholar reveals that, until July 2017, there was just one scientific publication that explicitly views the smart city as an organizational field: it is a study by Nyberg and Yarime [79] that describes the rise of a national-level smart city field in Japan. No study seems to exist yet that explores how local smart city organizational fields emerge at the level of specific cities, and particularly how the idiosyncratic configurations of such fields affect the cities' capability to actually evolve towards enhanced sustainability-enabling resilience and then sustainability transformations, as synthesized in Figure 1. The literature analysis, then, confirms the novelty of our research and its potential contribution to a viable emerging stream.

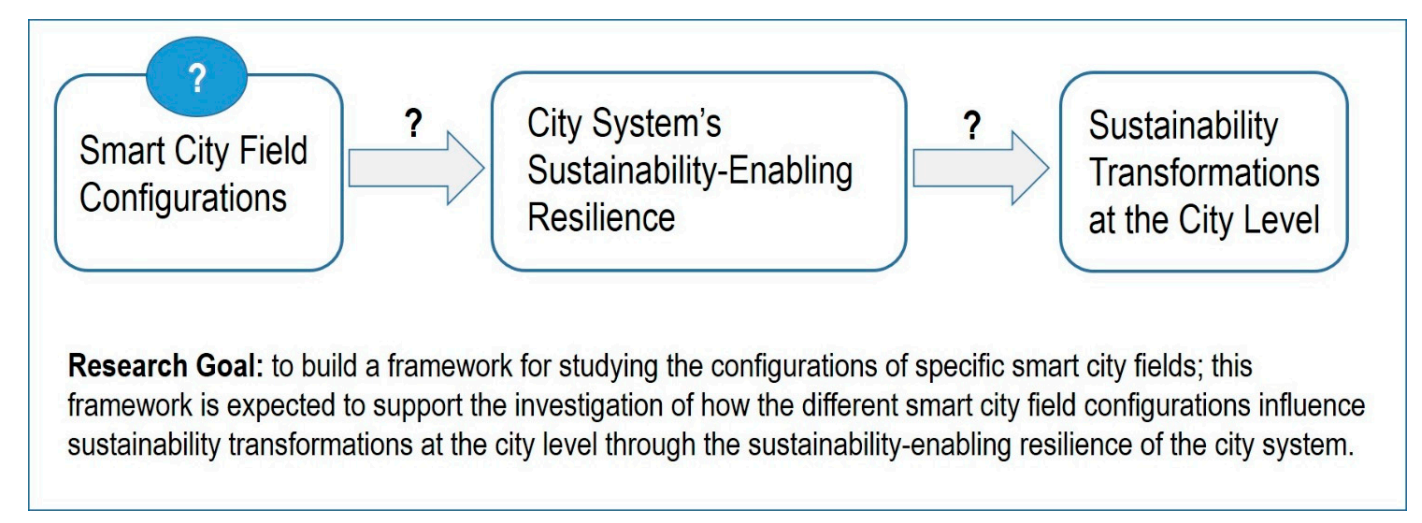

Figure 1. Research goal. Source: Authors' elaboration.

\section{Method}

Inductive studies [80] that are based on qualitative analyses [81] have been authoritatively encouraged as a proper research strategy to discover the organizational factors that are key to sustainability challenges [6].

Therefore, we leveraged a mix of primary and secondary sources of thick and complementary qualitative data. As for the primary sources, we conducted semi-structured interviews with city managers and entrepreneurs within seven European cities that have launched smart city projects and that differ significantly in size, history, geographical positions, and socio-economic contexts, as synthesized in Table 1. 
Table 1. Cities in which interviews on smart city initiatives have been conducted for this study. Source: Authors' elaboration.

\begin{tabular}{|c|c|c|c|c|c|}
\hline City & Country & Population & Geography-History & Economy & Interviews \\
\hline Amsterdam & Netherlands & $\begin{array}{l}\text { About } 2.4 \text { million } \\
\text { (whole metropolitan area) }\end{array}$ & $\begin{array}{l}\text { River and canals below sea level; North Sea; } \\
\text { oceanic climate; founded in the 14th century; } \\
\text { capital city. }\end{array}$ & $\begin{array}{l}\text { For centuries one of the top economic and } \\
\text { financial centers in Europe. Port activities. } \\
\text { Very attractive for international businesses. }\end{array}$ & $\begin{array}{l}\text { Two city government managers, } \\
\text { one entrepreneur }\end{array}$ \\
\hline Bilbao & Spain & $\begin{array}{l}\text { About } 1 \text { million } \\
\text { (whole metropolitan area) }\end{array}$ & $\begin{array}{l}\text { River; Bay of Biscay; mild oceanic climate; city } \\
\text { founded in the 14th century; Basque culture; } \\
\text { strong urban renewal since 1990s. }\end{array}$ & $\begin{array}{l}\text { Port activities; iron industry in 19th and 20th } \\
\text { century, then dramatic crisis; } \\
\text { de-industrialization, transition to service } \\
\text { economy, tourist surge since 2000s. }\end{array}$ & $\begin{array}{l}\text { One city government manager, } \\
\text { one entrepreneur }\end{array}$ \\
\hline Krakow & Poland & $\begin{array}{l}\text { About } 1.5 \text { million } \\
\text { (whole metropolitan area) }\end{array}$ & $\begin{array}{l}\text { River; valley; cold oceanic climate; city founded in } \\
\text { the 7th century; historical center and } \\
\text { natural reserves. }\end{array}$ & $\begin{array}{l}\text { Significant growth of the private sector since } \\
\text { the fall of communism. Attracts } \\
\text { multinational companies and foreign } \\
\text { investments in high-tech and outsourcing. }\end{array}$ & $\begin{array}{l}\text { Two city government managers, } \\
\text { one entrepreneur }\end{array}$ \\
\hline Tallin & Estonia & $\begin{array}{l}\text { About } 0.4 \text { million } \\
\text { (no wider metropolitan area) }\end{array}$ & $\begin{array}{l}\text { Gulf of Finland; humid continental climate; } \\
\text { Hanseatic League in the 14th-16th centuries; } \\
\text { capital city; historical center; independence from } \\
\text { USSR in } 1991 \text {. }\end{array}$ & $\begin{array}{l}\text { Significant growth of the private sector since } \\
\text { independence. Port-logistics; tourism; } \\
\text { Information Technology; strong initiatives to } \\
\text { attract high technology startups. }\end{array}$ & $\begin{array}{l}\text { One city government manager, } \\
\text { one entrepreneur }\end{array}$ \\
\hline Timişoara & Romania & $\begin{array}{l}\text { About } 0.3 \text { million } \\
\text { (no wider metropolitan area) }\end{array}$ & $\begin{array}{l}\text { Pannonian plain; continental climate; founded in } \\
\text { the 13th century; Sovietization from World War II } \\
\text { to the revolution in } 1989 .\end{array}$ & $\begin{array}{l}\text { Attracts significant foreign investments, } \\
\text { especially form Germany and Italy; today } \\
\text { considered the best business location in } \\
\text { Romania, especially for high-tech industries. }\end{array}$ & $\begin{array}{l}\text { One city government manager, } \\
\text { two entrepreneurs }\end{array}$ \\
\hline Turin & Italy & $\begin{array}{l}\text { About } 2.2 \text { million } \\
\text { (whole metropolitan area) }\end{array}$ & $\begin{array}{l}\text { Po valley and river; warm temperate climate; } \\
\text { founded in the 1st century BC; historical center; } \\
\text { formerly capital of the Kingdom of Italy. }\end{array}$ & $\begin{array}{l}\text { Major automotive and aerospace center. } \\
\text { Strong food and beverage industries. Recent } \\
\text { tourist surge and deindustrialization; } \\
\text { growth of high-tech sector and services. }\end{array}$ & $\begin{array}{l}\text { One city government manager, } \\
\text { two entrepreneurs }\end{array}$ \\
\hline Turku & Finland & $\begin{array}{l}\text { About } 0.3 \text { million } \\
\text { (whole metropolitan area) }\end{array}$ & $\begin{array}{l}\text { Baltic Sea and river; humid and cold continental } \\
\text { climate; founded in the 13th century, bridge } \\
\text { between Europe and the Russian Empire. }\end{array}$ & $\begin{array}{l}\text { Port; biotechnologies; information } \\
\text { technologies. Strong support to startups. } \\
\text { Domestic investments mainly. }\end{array}$ & $\begin{array}{l}\text { One city government manager, } \\
\text { two entrepreneurs }\end{array}$ \\
\hline
\end{tabular}


The interview protocol included questions about the ongoing smart city projects, the dynamics between the actors involved, and the interviewee's view about the key success factors, threats and opportunities of the smart city initiatives. The interviews, which lasted approximately $45 \mathrm{~min}$, were recorded and transcribed.

In addition, we selected a set of secondary sources providing complementary and high-quality contents, namely:

a. The website that IBM dedicated to its smart city initiatives worldwide. This source is particularly important because IBM was the actor that launched the successful "smarter cities challenge" in 2010, thus boosting the smart city movement dramatically at the global level. This website provides rich information on IBM's activities as a global vendor of smart city integrated solutions and consultancy (https://www.ibm.com/smarterplanet/us/en/smarter_cities/overview/).

b. The institutional website of IGLUS (innovative governance of large urban systems). This institution supports smart city innovation through advisory and educational initiatives. The website provides news and information on ongoing smart initiatives worldwide, along with access to numerous recorded interviews of practitioners involved in smart city projects (http://iglus.org/).

c. A portal that is specifically dedicated to smart city projects in the European Union (EU). This website provides a comprehensive list and relating descriptions of the numerous ongoing smart city projects that have been/are being developed based on EU funding (https://eusmartcities.eu/eu-projects).

d. The portal that the IEEE (institute of electrical and electronic engineers) dedicated to the conferences that revolve around the smart city challenges. This portal provides access to a big volume of interesting and original content. In particular, we leveraged the abstracts and presentations of 10 keynote speeches held in smart city conferences worldwide in the years 2012-2017 (http:/ / smartcities.ieee.org/conferences-events / past-events.html).

Through group work and discussion, we selected the most interesting and relevant content from the collected materials and transcribed it with a word processor to build a homogeneous archive for the analysis. The resulting archive of the content that was deemed to be relevant to this study includes approximately 280 pages.

These selected content was analyzed using Atlas.ti 7.0 software (ATLAS.ti Scientific Software Development $\mathrm{GmbH}$, Berlin, Germany). The authors collaboratively coded for three concepts that stem from the literature on organizational fields: (a) actors; (b) actors' roles; and (c) institutional logics. These three codes correspond to as many aspects that, according to the literature, are key to analyze the configuration of all organizational fields. In addition, the authors adopted a grounded approach [82] to let new codes emerge, that express further possible aspects that are specific to the configurational analysis of smart city organizational fields. Thanks to this mixed top-down and bottom-up coding, the authors inductively developed a framework for the configurational analysis of smart city fields based on the group discussion of the outcomes of coding in the light of the relevant literature.

\section{Results: Relevant Aspects for Mapping the Configuration of Smart City Fields}

The integrated analysis of the sources led to the identification of five key aspects that are particularly relevant for mapping the configuration of a specific smart city, viewed as an idiosyncratic and dynamically evolving organizational field. These five aspects are:

1. the Actors that (are expected to) play an active role in the co-creation of city resilience, sustainability and/or quality of life through ICT-enabled innovation;

2. the City Sub-Systems (such as mobility or waste) in which the actors (are expected to) play an active role in the co-creation of city resilience, sustainability and/or quality of life through ICT-enabled innovation; 
3. the Activity Layers, i.e., the specific levels in which actors (are expected to) contribute to the city sub-systems;

4. the Roles played by actors at each activity layer; and

5. the Institutional Logics enacting and enacted by the key actors of the smart city field.

Three of these five dimensions (Actors, Roles and Logics) are consistent with the key factors that can be deduced from the literature on organizational fields, while the remaining two dimensions (City Sub-Systems and Activity Layers) are specific to smart city fields and constitute a completely original contribution of this study to the identification of the key aspects of organizational fields. In the following paragraphs, each of these five dimensions of the configurational analysis of smart city fields will be analyzed in more detail.

\subsection{Actors}

In light of this study's approach and results, the Actors of a smart city's organizational field are all those social subjects (individuals, groups, organizations) that (are expected to) play an active role in the co-creation of city resilience, sustainability and/or quality of life by contributing to innovative city-level activity systems that are enabled by ICTs.

This is a quite strict definition: for example, the stakeholders of smart city projects (including e.g., all public transportation users) may be significantly more numerous than smart city field's Actors, which (differently from some stakeholders) are expected to be active contributors of smart initiatives and activity systems. In addition, a city-level networking approach is also essential for a social subject to be considered part of the smart city field. This means that, on the one side, a city government agency cannot build a smart city field by itself; on the other side, the other subjects become field Actors in that they collaborate (directly or indirectly) with at least one city government agency for ICT-enabled innovative activities aimed at improved city resilience, sustainability and/or quality of life.

Based on these criteria, the analysis of this study's sources results in a list of typical Actors of smart city fields, as in Table 2 (left).

Table 2. Typical Actors of smart city fields (left) and the City Sub-Systems in which several of these Actors typically contribute to smart initiatives (right). Source: Authors' elaboration.

\begin{tabular}{|c|c|}
\hline Actors & \\
\hline \multicolumn{2}{|l|}{ City government agencies } \\
\hline Other government bodies & City Sub-Systems \\
\hline Municipal utilities (e.g., public transport, sewage, energy) & Energy \\
\hline Health care centers & Mobility \\
\hline Other city institutions (e.g., libraries) & Waste \\
\hline Other partnering cities & Water and sewage \\
\hline Schools & Housing \\
\hline Non-profit organizations & Public spaces and buildings \\
\hline Associations and interest groups & Healthcare and wellbeing \\
\hline Working groups & Government, policy-making and bureaucracy \\
\hline Science and Technology parks & Safety and security \\
\hline Incubators, venture capitalists, business angels & Entertainment, sports and culture \\
\hline Local start-ups & Education, participation and inclusion \\
\hline $\begin{array}{l}\text { Universities and research centers (focusing on natural and/or } \\
\text { social sciences and/or technical disciplines } \\
\text { and/or humanities) }\end{array}$ & $\begin{array}{l}\text { Specific natural ecosystems at the city level } \\
\text { (e.g., the river, the hills, the marine area) }\end{array}$ \\
\hline $\begin{array}{l}\text { Already established providers/developers of smart solutions } \\
\text { (hardware, software and/or consultancy) (global or local) }\end{array}$ & $\begin{array}{l}\text { Specific industrial systems at the city level } \\
\text { (e.g., the harbor, the fashion district, the local } \\
\text { tourism system) }\end{array}$ \\
\hline \multicolumn{2}{|l|}{ Other businesses (e.g., solar panel producers) (global or local) } \\
\hline Smart City Organization (bridging role) & \\
\hline
\end{tabular}


The analysis also confirms that different cities display different configurations as for smart city field's Actors. Whilst a city government agency is always present in a smart city field, the other Actors' presence and contribution varies significantly from case to case. For example, some smart city fields include only technical universities, whilst others also include social sciences research centers. Some smart city fields include a technology park with incubators and local start-ups, but others do not. Some smart city fields witness the active participation of global players such as big ICT providers and consultancy firms, whilst others include only few and local businesses. Some smart cities build upon the outcomes of active and self-organizing working groups, open to all interested citizens and local entrepreneurs, while others have a much less participatory structure. Some smart city fields revolve around a proper smart city organization (e.g., a steering committee and secretariat) with a specific mission of bridging all the other actors and facilitating their collaboration, whilst other smart city fields lack a focal organization that is specifically dedicated to facilitating, orchestrating and/or coordinating all the other smart city Actors.

This study argues that this diversity of typologies of Actors included in different smart cities' organizational fields may result in several sets of different (possibly equifinal) combinations of actors' presence/absence that, under certain conditions, influence smart city performance, i.e., the city's resilience, sustainability and quality of life, in possibly predictable ways. Therefore, we suggest that the identification of the smart city organizational field's Actors is a key stage in the configurational analysis of smart cities.

\subsection{Sub-Systems}

Almost all of this study's primary and secondary sources identify smart projects, or initiatives, as a key attribute of smart cities. For example, some smart city fields experiment with new smart bins for optimizing waste collection, whilst others launch new systems of a smart electric grid in order to optimize energy consumption. Some smart cities optimize road repairs by providing citizens with smartphone apps to take pictures of potholes and send them to the municipality together with the GPS positioning of where the picture was taken. Others develop meters that signal abnormal patterns in the public water system's flows, thus enabling the identification of technical and/or behavioral problems that result in wasted water. One could make hundreds of examples of ongoing smart projects and initiatives worldwide, and this list is continuously updating. Therefore, using a list of smart projects/initiatives for building a configurational analysis framework seems quite problematic.

A possible solution, which allows comparisons on how different cities build their respective smart projects portfolios, is leveraging the concept of City Sub-Systems [11]. The analysis of this study's sources revealed that, in smart city fields, smart initiatives tend to accumulate around a limited number of City Sub-Systems; based on these sources, it is possible to draw a list of typical City Sub-Systems that may catalyze smart city projects, as in Table 2 (right).

The analysis of our primary and secondary sources confirms that different cities activate smart projects in different City Sub-Systems. For example, some cities launch smart projects in almost all the City Sub-Systems, whilst others concentrate their smart initiatives in just one or two City Sub-Systems. Some cities prioritize innovation in infrastructure-based Sub-Systems, such as energy or mobility, whilst others prioritize more intangible Sub-Systems, such as social inclusion or government. These choices are likely to be relevant to the different dimensions of smart city performance in terms of sustainability-enabling resilience and sustainability transformations at the city level. Therefore, we suggest that the analysis of which City Sub-Systems are involved in smart projects and initiatives be another key stage in the configurational analysis of smart city fields.

\subsection{Activity Layers}

Government activities traditionally concentrate on the development and maintenance of a suited common environment for civil coexistence. This environment can be viewed as made up of a physical dimension (e.g., roads, public parks, and sewage pipelines) and a socio-cultural dimension 
(e.g., common beliefs, laws, and practices). This is consistent with the widely adopted view of the city as a socio-technical [21] or social-ecological system [56].

The city environment, in its physical and socio-cultural dimensions, serves as a basis for developing services at the urban level. These services can be provided by the government itself, but also by other actors leveraging the opportunities of the urban environment. For example, roads can be used to provide postal services; a clean beach can be used to provide tourism services; and laws can be used to provide security services. In turn, these environment-enabled services enable the provision of further services and goods.

The smart city discourse that emerges from our analysis is consistent with this idea that the city environment, in its physical and socio-cultural aspects, is the essential basis for city resilience, sustainability and quality of life, both directly (citizens can use roads, for example) and indirectly (citizens are provided with services enabled by roads). However, our analysis also pinpoints that smart city projects usually involve a third layer lying between the environment layer and the service layer: the digital layer. Thanks to new technologies, both the physical and the social environment can automatically generate data, and these data can be leveraged to build innovative services [83]. For example, sensors on the roads can measure pollution, while the car drivers' cell phones can provide data on users' positions: these data can be combined to create a service that automatically suggests alternative routes to mitigate pollution peaks. In turn, these new services generate further data, which can be leveraged for decision making, further services, etc., and result in changes in both the physical and socio-cultural environment (Figure 2).

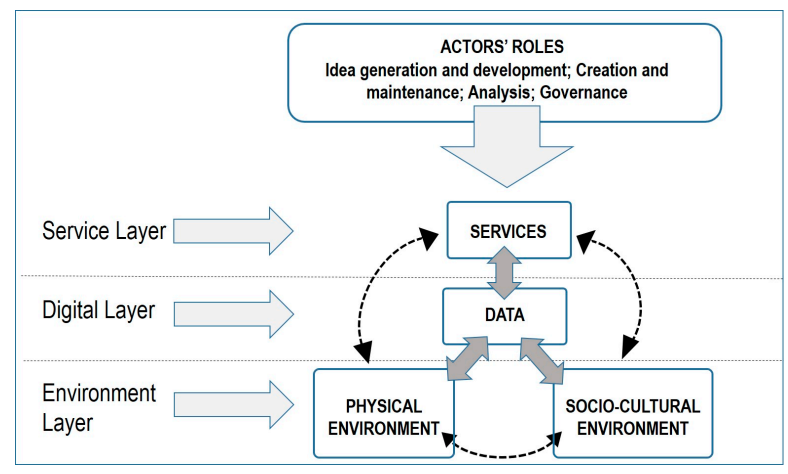

Figure 2. Activity Layers and actors' Roles in smart city fields. Source: Authors' elaboration.

The Actors of a smart city organizational field, by definition, are active at least at one level (environment, digital or service level) in at least one City Sub-System (e.g., energy or waste: see Table 2). This generates many possible combinations. In certain smart cities, the same Actor is active at all the Layers in a certain Sub-System: for example, a public transportation company can contribute to the physical layer (e.g., means of transport and subways), the digital layer (e.g., meters and sensors providing real-time data on urban transportation) and the (data-enabled) service layer (e.g., digital ticketing, and smartphone apps to inform on timetables or delays) of the mobility sub-system. In other contexts, different Actors are active at different Layers of the same Sub-System: for example, in some cities the municipal utility contributes to the environment layer, whilst a global ICT player builds the digital layer, and a local startup is key to the service layer.

According to this study's sources, the insertion of the digital layer and the consequent booming opportunities to develop new services injected further complexity in city systems. This results in critical challenges, for at least two reasons. On the one hand, actors can perceive that the creation of these new services is not economically sustainable: in these cases, although many data are available, these data are not used to develop innovative services, because no one finds a way to make money from these services. This results in a paradoxical lethargy, in which the investments made in innovating the environment and generating data do not result in perceivable benefits at the system level. On the other hand, an 
opposite problem can emerge when some actors exploit the environment and the data made available by the city to develop highly profitable services, while leaving to the citizens the costs of maintaining the infrastructures and providing the data essential to make the service possible. This so-called "uberization" of smart city fields is perceived as a serious threat from several city governments. In particular, big global players are often perceived as having more opportunities of "cream-skimming" opportunities from smart cities without proportionally contributing to the city system's costs.

In a nutshell, the configurational analysis of which Actors are active at which Activity Layers in each City Sub-System can provide insights on whether, how and why a certain smart city field is subject to the opposing threats of lethargy and free-riding. This analysis can also help understand the dynamics between traditional and emerging business models in a specific smart city field.

\subsection{Roles}

This study's primary and secondary sources converge in identifying some key recurrent Roles that actors may play while contributing to smart city initiatives.

These Roles can be listed as follows (Figure 2, top):

- (I)-Idea generation and development (of the environment, digital and/or service layer).

- (C) - Creation and maintenance (of the environment, digital and/or service layer).

- (A) -Analysis (of the environment, digital and/or service layer).

- (G)-Governance (of the environment, digital and/or service layer).

These Roles are distributed in different ways across different smart city fields. For example, in some cases the city government generates and develops an idea for a smart service, then outsources the activity of creation and maintenance of that service, but keeps the analysis and governance activities in-house. Conversely, in other cases, the idea is generated outside the city government that is in charge to implement it, whilst the analysis of the impact is left to a research center. In other words, many possible combinations are possible in this respect, as well. In addition, the analysis of actors' Roles can provide valuable insights on the business models emerging from a specific smart city field, especially if the analysis of actors' Roles is combined with the analysis of the Activity Layers presented in the previous paragraph (as synthesized in Figure 2).

\subsection{Logics}

The fifth step that, according to this study's sources, is particularly relevant to conduct an effective configurational analysis of smart city fields consists in understanding the Institutional Logics carried by the actors that participate in the fields under analysis.

Drawing up an inventory of the key typical Logics shaping smart city fields is not an easy task and required an intense cross-fertilization of all of the sources leveraged for this study. Luckily, a rich literature is already available on the extant and emerging institutional logics in today's scenario (see Section 2.1); the iterative use of this literature enabled the inductive efforts conducted to develop the list presented in Table 3.

For each Logic, a key literature reference is provided, along with a synthetic description of the Logic's core values and expectations. In addition, in order to better illustrate how different smart city issues, look like if watched through the glasses of different Institutional Logics, a statement is provided for each Logic, consistent with that Logic's view, on how the smart city's digital layer should be managed.

Table 3 shows that smart city fields can be shaped by several different Institutional Logics. Some of them are highly conflicting with each other, such as the innovation and the bureaucratic logic; others are partially compatible, such as the environmentalist and the equality logic; and others are highly compatible, such as the commons and the co-creation logic.

The analysis of this study's sources confirms that the co-existence of several different Institutional Logics plays a paradoxical role in the smart city organizational field: on the one side, this diversity enables field-level dynamism and cross-fertilization; on the other side, it continuously generates tensions that threaten the field with intractable conflicts, paralysis and failure. 
Table 3. Typical Institutional Logics shaping smart city fields. Source: Authors' elaboration.

\begin{tabular}{|c|c|c|c|}
\hline & Values and Expectations & Typical Approach to the Digital Layer & Ref. \\
\hline Innovation logic & $\begin{array}{l}\text { Focus on translating scientific research into innovation that contributes to economic } \\
\text { growth and quality of life; technology transfer; entrepreneurial initiatives; maximizing } \\
\text { opportunities for start-ups and university spin-offs; entrepreneurial risk-taking as a } \\
\text { value; creative destruction; innovation partnerships. }\end{array}$ & $\begin{array}{l}\text { Data should be available for entrepreneurs and } \\
\text { researchers, enabling the emergence of new ideas, } \\
\text { analyses and innovative solutions. }\end{array}$ & {$[84,85]$} \\
\hline Classical market logic & $\begin{array}{l}\text { Competition under clear rules; profit maximization; cost reduction; free enterprise; } \\
\text { individualism; short-termism. }\end{array}$ & Control of data is a source of competitive advantage. & [26] \\
\hline Bureaucratic logic & $\begin{array}{l}\text { Procedural correctness prevails over performance and results; rule setting and } \\
\text { enforcement as a guarantee of stability, continuity, neutrality and equity; secrecy; } \\
\text { hierarchy; legal rationality; power as a source of control. }\end{array}$ & $\begin{array}{l}\text { Control of data is a source of predictability, stability and } \\
\text { enforcement capability. }\end{array}$ & [86] \\
\hline Equality logic & $\begin{array}{l}\text { Redistribution of resources and opportunities to the weakest and most fragile people } \\
\text { and groups; inclusion; participation; human rights; fight against power and privilege; } \\
\text { suspicious attitude towards businesses and markets, viewed as forces that enhance } \\
\text { selfishness and inequalities; collectivism. }\end{array}$ & $\begin{array}{l}\text { Data must be open to the extent this does not threaten } \\
\text { the rights of socially disadvantaged people against } \\
\text { privileged and/or powerful actors. }\end{array}$ & [26] \\
\hline Environmentalist logic & $\begin{array}{l}\text { Ecosystems' equilibrium and resilience as key goals; focus on the environmental costs } \\
\text { and risks of economic development; sense of actors' responsibilities for the } \\
\text { environmental sustainability of decisions and behaviors; suspicious attitude towards } \\
\text { businesses and markets, viewed as forces that over-exploit and jeopardize natural } \\
\text { ecosystems; long-termism; collectivism. }\end{array}$ & $\begin{array}{l}\text { Data should be protected from misuse and } \\
\text { manipulation on the part of actors carrying economic or } \\
\text { power interests that may threaten the } \\
\text { natural environment. }\end{array}$ & [87] \\
\hline Predatory logic & $\begin{array}{l}\text { Focus on maximizing rents while minimizing the need to respect any external rules; } \\
\text { harsh and ruthless competition; free-riding as a sign of cunning; maximizing } \\
\text { appropriation while providing as little as possible in return, especially in terms of } \\
\text { collective good; power and control over other actors as source of } \\
\text { privilege; individualism. }\end{array}$ & $\begin{array}{l}\text { Data control and exploitation are valuable sources of } \\
\text { power and value appropriation. }\end{array}$ & [88] \\
\hline Commons logic & $\begin{array}{l}\text { Focus on protecting/developing common resources that are fragile to actors' } \\
\text { disengagement, misappropriation and/or lack of organizational integration; sense of } \\
\text { actors' responsibility and interconnected fates; transparence and horizontal } \\
\text { accountability; collective arrangements; legitimated enforcement of } \\
\text { commons-protecting and commons-enabling rules; long-termism. }\end{array}$ & $\begin{array}{l}\text { Data must be open to the extent this does not threaten } \\
\text { the protection and development of critical commons. }\end{array}$ & [7] \\
\hline Co-creation (hybrid) logic & $\begin{array}{l}\text { Respectful multi-sided interactions; different logics viewed as complementary } \\
\text { resources rather than opposing categorical imperatives; collaboration of all parties for } \\
\text { the development of knowledge, relationships, rules, and/or projects of common } \\
\text { interest; focus on distributed experimentation, participatory sense-making, and } \\
\text { concrete problem solving. }\end{array}$ & $\begin{array}{l}\text { It is important to enable data and knowledge sharing } \\
\text { among all actors that participate in } \\
\text { co-creation processes. }\end{array}$ & [89] \\
\hline
\end{tabular}


An accurate analysis is likely to reveal that all Institutional Logics are present in almost all smart city organizational fields. However, the literature suggests that scholars concentrate on the dominant Institutional Logics, i.e., the logics carried by focal actors with relevant roles at the environment, digital and service layers, because these actors are in the position to effectively influence the institutional dynamics in their local networks.

Focusing on dominant logics allows for the discovery of interesting differences from field to field. For example, in one of the cases analyzed for this study, the field is mainly shaped by the equality logic, the environmentalist logic and the co-creation logic, whilst in another case the field is strongly shaped by the innovation logic, the commons logic and the market logic. These results suggest that the identification of dominant logics is a key step in the configurational analysis of smart city fields.

\section{A Framework for the Integrated Configurational Analysis of Smart City Organizational Fields}

The inductive analysis described above allows for the build-up of a five-dimensional framework for the integrated configurational analysis of smart city organizational fields.

The five dimensions refer to the five aspects under which smart city fields can take significant different configurations, i.e., Actors, Sub-systems, Activity Layers, Roles and Logics.

Although these five dimensions refer to intertwining phenomena, they are clearly distinguishable: therefore, the analysis can be conducted on just one or some of these aspects at a time. The opportunity to limit the number of possible combinations to be considered for a single analysis could be particularly useful, for example, in Qualitative Comparative Analysis (QCA) when the number of cases to be compared is limited $[90,91]$. However, the framework presented by this study is also conceived to support the integrated analysis of all of the five aspects, which is particularly interesting, for example, for conducting in-depth longitudinal analyses and/or natural experiments on a specific smart city field [92]. Under these research designs, the five-dimensional framework could provide a good level of complexity and granularity to support discussions, evaluations and decisions regarding smart city governance, management and entrepreneurial opportunities.

Based on our pilot experimentations in data collection and structuring, we suggest that the integrated configurational analysis of the smart city field be conducted in two stages.

In the first stage, a high-level analysis is conducted, in order to identify to what extent City Sub-Systems (see Table 2) are active, i.e., host smart initiatives; and to what extent the different active Sub-System collaborate with other city Sub-Systems engaged in smart initiatives, thus overcoming traditional organizational boundaries and departmental competences. The results can be synthesized like in Table 4 , which is given as an example.

In the second stage of the configurational analysis, more specific information is considered. For each City Sub-System that has been identified as active in the previous stage, Actors are identified, along with their Role(s) and the Activity Layer(s) they contribute to. Finally, the Institutional Logics carried by the actors are identified. The results can be synthesized in a table like Table 5 .

Table 4. Example of how the proposed framework can be used for identifying the level of engagement and integration of City Sub-Systems in the smart city organizational field. Source: Authors' elaboration.

\begin{tabular}{ccc}
\hline City Sub-System & $\begin{array}{c}\text { Engagement in Smart } \\
\text { Initiatives }\end{array}$ & $\begin{array}{c}\text { Knowledge Exchange with Other } \\
\text { Sub-Systems Engaged in Smart Initiatives }\end{array}$ \\
\hline Energy & High & Medium \\
Mobility & High & Medium \\
Waste & Low & Low \\
Water and sewage & Medium & Low \\
Housing & Low & Medium \\
Public spaces and buildings & Medium & High \\
\hline
\end{tabular}

Example of table reading: The city sub-system "energy" is highly engaged in smart city initiatives, and its level of knowledge exchange with other sub-systems engaged in smart initiatives is medium. 
Table 5. Example of how the proposed framework can be used for the integrated analysis of a Smart City Sub-System's organizational field. Source: Authors' elaboration.

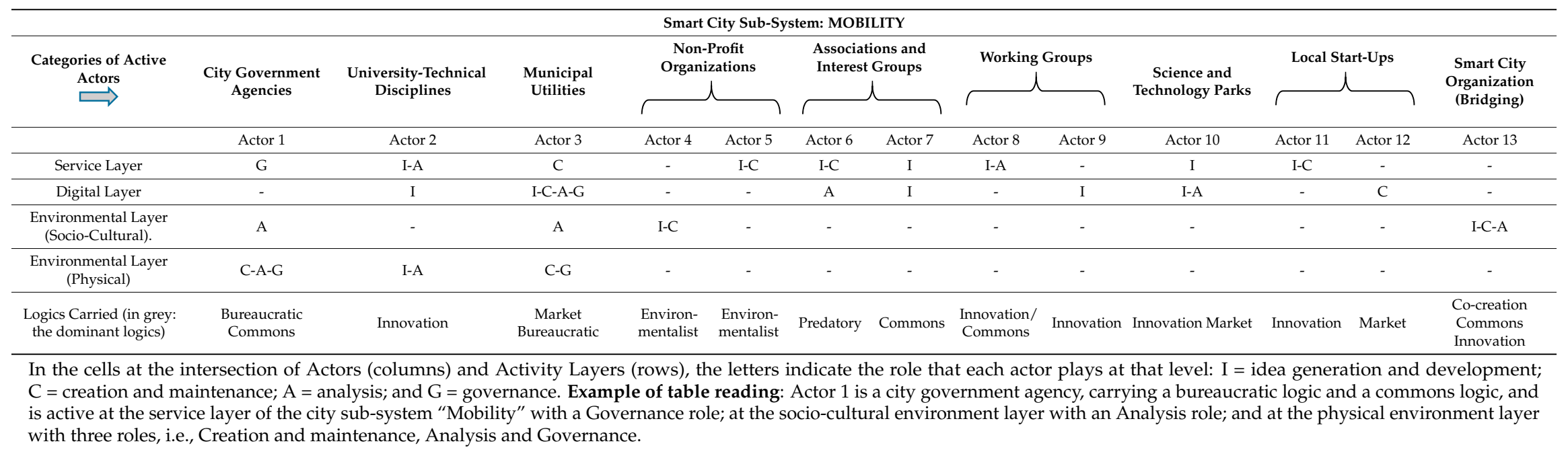




\section{Conclusions}

The adoption of a configurational approach to smart city phenomena confirms that smart cities can be usefully conceptualized as place-specific organizational fields. In addition, our analysis highlights that smart cities are pluralistic and incoherent social organisms, with blurred boundaries and conflicting logics, faced with extremely complex challenges. This paves the way to a better understanding of the reasons why the traditional mechanisms of strategic planning, markets, and hierarchical control, are often insufficient to achieve the success of smart city initiatives.

The intrinsic contradictions and complexities of smart city fields are at the root of this type of field's weaknesses and strengths. On the one side, these contradictions and complexities may result in resource waste, poor efficiency and effectiveness, or even the total paralysis of smart initiatives. On the other side, these contradictions and complexities can work as powerful engines of distributed entrepreneurial dynamism and participatory innovation. Our study's results suggest, in fact, that the great potential of the smart city field lies in its capability to activate virtuous cycles of hybridization that inject aspects of the entrepreneurial mindset in subjects that traditionally lack this attitude (such as social movements or government bodies), while investing in entrepreneurship the urge and capabilities to participate in sustainability-oriented institutional work.

A configurational approach to smart city fields enables researchers and practitioners to understand that the smart city is not just a policy idea, or strategy, but rather a new social organism that, under certain combinations of conditions, can enable the collaboration of diverse actors in an innovative activity system and support the rise of a new generation of entrepreneurship. In smart city fields, the most advanced experimentations on big data and IoT have to tackle unprecedented challenges in complex urban contexts, thus serving as irreplaceable natural laboratories for sustainability-enabling resilience and sustainability transformations.

This study, of course, has limitations, which correspond to opportunities for further research. Given its explorative nature, this article provides a framework that has been developed through inductive processes and this far has received face validation only for the exhaustiveness and mutual exclusivity of the identified categories. The application of this framework in systematic data collection processes will allow for its more rigorous testing and possibly fine-tuning. In other words, we propose our results as a basis for incremental learning on smart cities as complex organization and management challenges.

Understanding the factors and dynamics that trigger and support vicious and virtuous cycles at the level of smart city organizational fields is a critical step in this pioneering phase of smart city studies. We hope that this study contributes to take this step.

Author Contributions: All three authors contributed to the writing of this manuscript. Paul Pierce was particularly engaged in the data collection phase; Francesca Ricciardi in the literature analysis and framework development phases; and Alessandro Zardini in the data analysis phase.

Conflicts of Interest: The authors declare no conflict of interest.

\section{References}

1. Ferraro, F.; Etzion, D.; Gehman, J. Tackling Grand Challenges Pragmatically: Robust Action Revisited. Organ. Stud. 2015, 36, 363-390. [CrossRef]

2. Allan, C.; Curtis, A. Nipped in the Bud: Why Regional Scale Adaptive Management Is Not Blooming. Environ. Manag. 2005, 36, 414-425. [CrossRef] [PubMed]

3. Berkes, F. Evolution of co-management: Role of knowledge generation, bridging organizations and social learning. J. Environ. Manag. 2009, 90, 1692-1702. [CrossRef] [PubMed]

4. Armitage, D.R.; Plummer, R.; Berkes, F.; Arthur, R.I.; Charles, A.T.; Davidson-Hunt, I.J.; Diduck, A.P.; Doubleday, N.C.; Johnson, D.S.; Marschke, M.; et al. Adaptive co-management for social-ecological complexity. Front. Ecol. Environ. 2008, 7, 95-102. [CrossRef] 
5. Cantino, V.; Devalle, A.; Cortese, D.; Ricciardi, F.; Longo, M. Place-based network organizations and embedded entrepreneurial learning: Emerging paths to sustainability. Int. J. Entrep. Behav. Res. 2017, 23, 504-523. [CrossRef]

6. Eisenhardt, K.M.; Graebner, M.E.; Sonenshein, S. Grand Challenges and Inductive Methods: Rigor without Rigor Mortis. Acad. Manag. J. 2016, 59, 1113-1123. [CrossRef]

7. Ansari, S.; Wijen, F.; Gray, B. Constructing a climate change logic: An institutional perspective on the "tragedy of the commons". Organ. Sci. 2013, 24, 1014-1040. [CrossRef]

8. Wooten, M.; Hoffman, A.J. Organizational Fields: Past, Present, and Future. In Handbook of Organizational Institutionalism; Greenwood, R., Oliver, C., Suddaby, R., Sahlin, K., Eds.; Sage Publications: Washington, DC, USA, 2008; pp. 130-147. ISBN 9781849200387.

9. Etzion, D.; Gehman, J.; Ferraro, F.; Avidan, M. Unleashing sustainability transformations through robust action. J. Clean. Prod. 2017, 140, 167-178. [CrossRef]

10. Ahvenniemi, H.; Huovila, A.; Pinto-Seppä, I.; Airaksinen, M. What are the differences between sustainable and smart cities? Cities 2017, 60, 234-245. [CrossRef]

11. Dameri, R.P.; Ricciardi, F. Smart City Intellectual Capital: An emerging view of territorial systems innovation management. J. Intellect. Cap. 2015, 16, 860-887. [CrossRef]

12. Marsal-Llacuna, M.L.; Colomer-Llinàs, J.; Meléndez-Frigola, J. Lessons in urban monitoring taken from sustainable and livable cities to better address the Smart Cities initiative. Technol. Forecast. Soc. Chang. 2015, 90, 611-622. [CrossRef]

13. Marsal-Llacuna, M.-L. City Indicators on Social Sustainability as Standardization Technologies for Smarter (Citizen-Centered) Governance of Cities. Soc. Indic. Res. 2016, 128, 1193-1216. [CrossRef]

14. Yigitcanlar, T.; Kamruzzaman, M. Planning, Development and Management of Sustainable Cities: A Commentary from the Guest Editors. Sustainability 2015, 7, 14677-14688. [CrossRef]

15. Kraus, S.; Richter, C.; Papagiannidis, S.; Durst, S. Innovating and Exploiting Entrepreneurial Opportunities in Smart Cities: Evidence from Germany. Creat. Innov. Manag. 2015, 24, 601-616. [CrossRef]

16. Bolton, R.; Hannon, M. Governing sustainability transitions through business model innovation: Towards a systems understanding. Res. Policy 2016, 45, 1731-1742. [CrossRef]

17. Huarng, K.-H.; Ribeiro-Soriano, D. Developmental management: Theories, methods, and applications in entrepreneurship, innovation, and sensemaking. J. Bus. Res. 2014, 67, 657-662. [CrossRef]

18. Almirall, E.; Wareham, J.; Ratti, C.; Conesa, P.; Bria, F.; Gaviria, A.; Edmondson, A. Smart Cities at the Crossroads. Calif. Manag. Rev. 2016, 59, 141-152. [CrossRef]

19. Glasmeier, A.; Nebiolo, M. Thinking about Smart Cities: The Travels of a Policy Idea that Promises a Great Deal, but So Far Has Delivered Modest Results. Sustainability 2016, 8, 1122. [CrossRef]

20. Pierce, P.; Andersson, B. Challenges with smart cities initiatives-A municipal decision makers' perspective. In Proceedings of the 50th Hawaii International Conference on System Sciences, Waikoloa, HI, USA, 4-7 January 2017; pp. 1-12.

21. Richter, C.; Kraus, S.; Syrjä, P. The Smart City as an opportunity for entrepreneurship. Int. J. Entrep. Ventur. 2015, 7, 211-226. [CrossRef]

22. Pache, A.-C.A.C.; Santos, F. When worlds collide: The internal dynamics of organizational responses to conflicting institutional demands. Acad. Manag. Rev. 2010, 35, 455-476. [CrossRef]

23. Heugens, P.P.M.A.R.; Lander, M.W. Structure! agency! (and other quarrels): A meta-analysis of institutional theories of organization. Acad. Manag. J. 2009, 52, 61-85. [CrossRef]

24. Lounsbury, M.; Beckman, C.M. Celebrating organization theory. J. Manag. Stud. 2015, 52, 288-308. [CrossRef]

25. De Vaujany, F.-X.; Vaast, E. If these walls could talk: The mutual construction of organizational space and legitimacy. Organ. Sci. 2014, 25, 713-731. [CrossRef]

26. Thornton, P.H.; Ocasio, W.; Lounsbury, M. The Institutional Logics Perspective: Foundations, Research, and Theoretical Elaboration; Oxford University Press: Oxford, UK, 2012.

27. Smets, M.; Morris, T.; Greenwood, R. From practice to field: A multilevel model of practice-driven institutional change. Acad. Manag. J. 2012, 55, 877-904. [CrossRef]

28. Lawrence, T.; Hardy, C.; Phillips, N. Institutional Effects of Interorganizational Collaborations: The Emergency of Proto-Institutions. Acad. Manag. J. 2002, 45, 281-290. [CrossRef]

29. Lawrence, T.B.; Leca, B.; Zilber, T.B. Institutional Work: Current Research, New Directions and Overlooked Issues. Organ. Stud. 2013, 34, 1023-1033. [CrossRef] 
30. Tracey, P.; Phillips, N.; Jarvis, O. Bridging institutional entrepreneurship and the creation of new organizational forms: A multilevel model. Organ. Sci. 2011, 22, 60-80. [CrossRef]

31. Dunn, M.B.; Jones, C. Institutional logics and institutional pluralism: The contestation of care and science logics in medical education, 1967-2005. Adm. Sci. Q. 2010, 55, 114-149. [CrossRef]

32. Purdy, J.M.; Gray, B. Conflicting logics, mechanisms of diffusion, and multilevel dynamics in emerging institutional fields. Acad. Manag. J. 2009, 52, 355-380. [CrossRef]

33. Besharov, M.L.; Smith, W.K. Multiple institutional logics in organizations: Explaining their varied nature and implications. Acad. Manag. Rev. 2014, 39, 364-381. [CrossRef]

34. Hutchins, M.J.; Sutherland, J.W. An exploration of measures of social sustainability and their application to supply chain decisions. J. Clean. Prod. 2008, 16, 1688-1698. [CrossRef]

35. Morelli, J. Environmental sustainability: A definition for environmental professionals. J. Environ. Sustain. 2011, 1, 2. [CrossRef]

36. Maxwell, D.; Van der Vorst, R. Developing sustainable products and services. J. Clean. Prod. 2003, 11, 883-895. [CrossRef]

37. Arcese, G.; Lucchetti, M.C.; Merli, R. Social life cycle assessment as a management tool: Methodology for application in tourism. Sustainability 2013, 5, 3275-3287. [CrossRef]

38. Van Wijk, J.; Stam, W.; Elfring, T.; Zietsma, C.; Den Hond, F. Activists and incumbents structuring change: The interplay of agency, culture, and networks in field evolution. Acad. Manag. J. 2013, 56, 358-386. [CrossRef]

39. Wittneben, B.B.F.; Okereke, C.; Banerjee, S.B.; Levy, D.L. Climate Change and the Emergence of New Organizational Landscapes. Organ. Stud. 2012, 33, 1431-1450. [CrossRef]

40. Vanolo, A. The Fordist city and the creative city: Evolution and resilience in Turin, Italy. City Cult. Soc. 2015, 6, 69-74. [CrossRef]

41. Kantur, D.; Iseri-Say, A. Measuring Organizational Resilience: A Scale Development. J. Bus. Econ. Financ. 2015, 4, 456. [CrossRef]

42. Plummer, R.; Armitage, D. A resilience-based framework for evaluating adaptive co-management: Linking ecology, economics and society in a complex world. Ecol. Econ. 2007, 61, 62-74. [CrossRef]

43. Folke, C. Resilience: The emergence of a perspective for social-ecological systems analyses. Glob. Environ. Chang. 2006, 16, 253-267. [CrossRef]

44. Cappa, F.; Del Sette, F.; Hayes, D.; Rosso, F. How to Deliver Open Sustainable Innovation: An Integrated Approach for a Sustainable Marketable Product. Sustainability 2016, 8, 1341. [CrossRef]

45. Chiles, T.H.; Bluedorn, A.C.; Gupta, V.K. Beyond creative destruction and entrepreneurial discovery: A radical Austrian approach to entrepreneurship. Organ. Stud. 2007, 28, 467-493. [CrossRef]

46. Lachmann, L.M. The Legacy of Max Weber; Glendessary: Berkley, CA, USA, 1970.

47. Thornton, P.H.; Ribeiro-Soriano, D.; Urbano, D. Socio-Cultural Factors and Entrepreneurial Activity: An Overview. Int. Small Bus. J. 2011, 29, 105-118. [CrossRef]

48. Dorado, S. Institutional entrepreneurship, partaking, and convening. Organ. Stud. 2005, 26, 385-414. [CrossRef]

49. Garud, R.; Hardy, C.; Maguire, S. Institutional Entrepreneurship as Embedded Agency: An Introduction to the Special Issue. Organ. Stud. 2007, 28, 957-969. [CrossRef]

50. Pacheco, D.F.; York, J.G.; Dean, T.J.; Sarasvathy, S.D. The coevolution of institutional entrepreneurship: A tale of two theories. J. Manag. 2010, 36, 974-1010. [CrossRef]

51. Schaltegger, S.; Wagner, M. Sustainable entrepreneurship and sustainability innovation: Categories and interactions. Bus. Strateg. Environ. 2011, 20, 222-237. [CrossRef]

52. Ricciardi, F.; Za, S. Smart City Research as an Interdisciplinary Crossroads: A Challenge for Management and Organization Studies. In From Information to Smart Society: Environment, Politics and Economics. Lecture Notes in Information Systems and Organisation, Volume 5; Mola, L., Pennarola, F., Eds.; Springer: Basel, Switzerland, 2014; pp. 163-171.

53. Abella, A.; Ortiz-de-Urbina-Criado, M.; De-Pablos-Heredero, C. A model for the analysis of data-driven innovation and value generation in smart cities' ecosystems. Cities 2017, 64, 47-53. [CrossRef]

54. Berrone, P.; Ricart, J.E.; Carrasco, C. The Open Kimono. Calif. Manag. Rev. 2016, 59, 39-70. [CrossRef]

55. Akçura, M.T.; Avci, S.B. How to make global cities: Information communication technologies and macro-level variables. Technol. Forecast. Soc. Chang. 2014, 89, 68-79. [CrossRef] 
56. Romolini, M.; Bixler, R.P.; Grove, J.M. A social-ecological framework for urban stewardship network research to promote sustainable and resilient cities. Sustainability 2016, 8. [CrossRef]

57. Alizadeh, T. An investigation of IBM's Smarter Cites Challenge: What do participating cities want? Cities 2017, 63, 70-80. [CrossRef]

58. Marsal-Llacuna, M.-L.; Segal, M.E. The Intelligenter Method (I) for making "smarter" city projects and plans. Cities 2016, 55, 127-138. [CrossRef]

59. Angelidou, M. Smart cities: A conjuncture of four forces. Cities 2015, 47, 95-106. [CrossRef]

60. Anthopoulos, L. Smart utopia VS smart reality: Learning by experience from 10 smart city cases. Cities 2017, 63, 128-148. [CrossRef]

61. Hollands, R.G. Critical interventions into the corporate smart city. Camb. J. Reg. Econ. Soc. 2015, 8, 61-77. [CrossRef]

62. Fjeldstad, O.D.; Snow, C.C.; Raymond, E.M.; Lettl, C. The architecture of collaboration. Strateg. Manag. J. 2012, 33, 734-750. [CrossRef]

63. Chelleri, L.; Kua, H.W.; Sánchez, J.P.R.; Md Nahiduzzaman, K.; Thondhlana, G. Are people responsive to a more sustainable, decentralized, and user-driven management of urban metabolism? Sustainability 2016, 8 , 275. [CrossRef]

64. Snow, C.C.; Håkonsson, D.D.; Obel, B. A Smart City Is a Collaborative Community: Lessons from Smart Aarhus. Calif. Manag. Rev. 2016, 59, 92-108. [CrossRef]

65. Muñoz, P.; Cohen, B. The making of the urban entrepreneur. Calif. Manage. Rev. 2016, 59, 71-91. [CrossRef]

66. Ribeiro Soriano, D.; Peris-Ortiz, M. Subsidizing technology: How to succeed. J. Bus. Res. 2011, 64, $1224-1228$. [CrossRef]

67. Ribeiro Soriano, D.; Huarng, K.-H. Innovation and entrepreneurship in knowledge industries. J. Bus. Res. 2013, 66, 1964-1969. [CrossRef]

68. Roig Dobon, S.; Ribeiro Soriano, D. Exploring alternative approaches in service industries: The role of entrepreneurship. Serv. Ind. J. 2008, 28, 877-882. [CrossRef]

69. Cappa, F.; Laut, J.; Nov, O.; Giustiniano, L.; Porfiri, M. Activating social strategies: Face-to-face interaction in technology-mediated citizen science. J. Environ. Manag. 2016, 182, 374-384. [CrossRef] [PubMed]

70. Dickinson, J.L.; Shirk, J.; Bonter, D.; Bonney, R.; Crain, R.L.; Martin, J.; Phillips, T.; Purcell, K. The current state of citizen science as a tool for ecological research and public engagement. Front. Ecol. Environ. 2012, 10, 291-297. [CrossRef]

71. Newman, G.; Wiggins, A.; Crall, A.; Graham, E.; Newman, S.; Crowston, K. The future of citizen science: Emerging technologies and shifting paradigms. Front. Ecol. Environ. 2012, 10, 298-304. [CrossRef]

72. Lombardi, P.; Giordano, S.; Farouh, H.; Yousef, W. Modelling the smart city performance. Innov. Eur. J. Soc. Sci. Res. 2012, 25, 137-149. [CrossRef]

73. Michelucci, F.V.; De Marco, A. Smart communities inside local governments: A pie in the sky? Int. J. Public Sect. Manag. 2017, 30, 2-14. [CrossRef]

74. Lee, J.H.; Hancock, M.G.; Hu, M.C. Towards an effective framework for building smart cities: Lessons from Seoul and San Francisco. Technol. Forecast. Soc. Chang. 2014, 89, 80-99. [CrossRef]

75. Cohen, B.; Almirall, E.; Chesbrough, H. The City as a Lab. Calif. Manage. Rev. 2016, 59, 5-13. [CrossRef]

76. Nicholds, A.; Gibney, J.; Mabey, C.; Hart, D. Making sense of variety in place leadership: The case of England's smart cities. Reg. Stud. 2017, 51, 249-259. [CrossRef]

77. Kim, K.; Jung, J.K.; Choi, J.Y. Impact of the smart city industry on the Korean national economy: Input-output analysis. Sustainability 2016, 8, 649. [CrossRef]

78. Santos, F.; Eisenhardt, K. Constructing markets and shaping boundaries: Entrepreneurial power in Nascent fields. Acad. Manag. J. 2009, 52, 643-671. [CrossRef]

79. Nyberg, R.A.; Yarime, M. Assembling a field into place: Smart-city development in Japan. Res. Sociol. Organ. 2017, 50, 253-279. [CrossRef]

80. Pettigrew, A. Longitudinal Field Research on Change: Theory and Practice. Organ. Sci. 1990, 1, $267-292$. [CrossRef]

81. Bryman, A.; Bell, E. Business Research Methods; Oxford University Press: Oxford, UK, 2011.

82. Gioia, D.A.; Corley, K.G.; Hamilton, A.L. Seeking Qualitative Rigor in Inductive Research: Notes on the Gioia Methodology. Organ. Res. Methods 2013, 16, 15-31. [CrossRef] 
83. Sole Parellada, F.; Ribeiro Soriano, D.; Huarng, K.-H. An overview of the service industries' future (priorities: Linking past and future). Serv. Ind. J. 2011, 31, 1-6. [CrossRef]

84. Vásquez-Urriago, Á.; Barge-Gil, A.; Modrego, A. Science and technology parks and cooperation for innovation: Empirical evidence from Spain. Res. Policy 2012, 45, 137-147. [CrossRef]

85. Miller, F.A.; French, M. Organizing the entrepreneurial hospital: Hybridizing the logics of healthcare and innovation. Res. Policy 2016, 45, 1534-1544. [CrossRef]

86. Meyer, R.; Hammerschmid, G. Public Management Reform: An Identity Project. Public Policy Adm. 2006, 21, 99-115. [CrossRef]

87. Van Bommel, K.; Spicer, A. Hail the snail: Hegemonic struggles in the slow food movement. Organ. Stud. 2011, 32, 1717-1744. [CrossRef]

88. Evans, P.B. Predatory, developmental, and other apparatuses: A comparative political economy perspective on the third world state. Sociol. Forum 1989, 4, 561-587. [CrossRef]

89. Schuttenberg, H.Z.; Guth, H.K. Seeking our shared wisdom: A framework for understanding knowledge coproduction and coproductive capacities. Ecol. Soc. 2015, 20, 1-15. [CrossRef]

90. Fiss, P. Building better causal theories: A fuzzy set approach to typologies in organization research. Acad. Manag. J. 2011, 54, 393-420. [CrossRef]

91. Ragin, C.C. Redesigning Social Inquiry: Fuzzy Sets and Beyond; Chicago University Press: Chicago, IL, USA, 2008.

92. Grant, A.M.; Wall, T.D. The neglected science and art of quasi-experimentation: Why-to, when-to, and how-to advice for organizational researchers. Organ. Res. Methods 2009, 12, 653-686. [CrossRef]

(C) 2017 by the authors. Licensee MDPI, Basel, Switzerland. This article is an open access article distributed under the terms and conditions of the Creative Commons Attribution (CC BY) license (http://creativecommons.org/licenses/by/4.0/). 